\title{
Performance of Fire Risk Estimates Based on Soil Moisture of Selected Peat Land Use
}

\author{
Holidi $^{1,2}, M$ Edi Armanto ${ }^{3}$, Nurhayati Damiri ${ }^{3}$, and Dinar Dwi Anugerah Putranto ${ }^{4}$ \\ ${ }^{1}$ Study Program of Environmental Science, Universitas Sriwijaya, South Sumatera, Indonesia \\ ${ }^{2}$ Faculty of Agriculture, Musi Rawas University, South Sumatra, Indonesia \\ ${ }^{3}$ Faculty of Agriculture, Universitas Sriwijaya, South Sumatra, Indonesia \\ ${ }^{4}$ Faculty of Engineering, Universitas Sriwijaya, South Sumatra, Indonesia
}

\begin{abstract}
Each peat land used has a different vegetation that will influences peat soil moisture during dry seasons. The level of fire risk depends on peat soil moisture in every land used. The objective of this research was to evaluate the variability of peat soil moisture at different peat land used during dry season and its impact on fire risk The research was carried on peat land with four types of land used located Sub District of Pedamaran, Ogan Komering Ilir District South Sumatera Province was held from June 2018 to July 2018. We investigated soil moisture variability in this site to a depth $30 \mathrm{~cm}$ under four type of peat land used during dry season 2018. The result of the research showed that on the second month of the dry season all peat soil to $30 \mathrm{~cm}$ depth have soil moisture category moderate fire risk except on secondary forest category at low risk fire. The higher fire risk of the land used the more attention we must focus to prevent the fire.
\end{abstract}

\section{Introduction}

Peat lands are land that is formed due to the accumulation of organic material that is always inundated, especially in the rainy season and plays an important ecological role in regulating hydrology, carbon storage and biodiversity.

The area of peat land in Indonesia reaches 20.6 million hectares which are spread predominantly in Sumatra, Kalimantan and Papua. Especially for South Sumatra Province peat lands include 1.48 million hectares of peat mineral soil, of which Ogan Komering Ilir district has 769 thousand ha or 51.8 percent of the peat lands of South Sumatra Province [1]

12.9 million hectares of 27.1 million hectares of peat lands in Southeast Asia have occurred deforestation and land conversion [2]. Peat lands areas in the Sumatra region experience a degradation of 1.25 million hectares or around 29.5 percent of the area of peat land [3]. One of the impacts resulting from the conversion of peat lands from forest to nonforest is drought due to draining of land for agricultural cultivation purposes $[4][5][6]$

\footnotetext{
*Corresponding author: holidi@student.pps.unsri.ac.id
} 
Each peat land used has a different level of fire hazard depending on the fuel water content[7]. On land with a forest system, it is very good at absorbing rainwater and has the ability to hold high water compared to shrubs and grasses[8]. This condition also causes differences in fuel water fluctuations in each use in the rainy and dry season.

Peat soil water content in good condition can reach more than $850 \%$ of its dry weight [9]. Peat soil with a water content of less than $115 \%$ will have a high fire risk, water content between 115 to $135 \%$ the risk of moderate fire and more than $135 \%$ of the risk of low fire [10].

The objective of this research was to evaluate the variability peat soil moisture of selected land use on peat during dry season and its impact on fire risk.

\section{Materials and Methods}

The research was carried out on dome peat in Pedamaran Sub-district at Ogan Komering Ilir District at South Sumatera Province, Indonesia, with position between $104^{\circ} 50^{\prime} 15^{\prime \prime}-105^{\circ} 4^{\prime} 30^{\prime \prime}$ East and $3^{\circ} 14^{\prime} 15^{\prime \prime}-3^{\circ} 31^{\prime} 45^{\prime \prime}$ Southern hemispere. There are four land used classified, secondary forest, oil palm, bush and grass (Fig 1). The research was carried out from June 2018 to August 2018 where dry season occurred. This area has annual rainfall more than $2.500 \mathrm{~mm}$ per year. Moisture content was calculated using oven drying at $105^{\circ} \mathrm{C}$ for two days. Five peat samples of each land use was taken randomly at 0 $10 \mathrm{~cm}, 10-20 \mathrm{~cm}$ and $20-30 \mathrm{~cm}$. Analysis of soil moisture, bulk density, C-organic was carried out in the soil science laboratory of Sriwijaya University and Musi Rawas University. Soil moisture data was analyzed statistically by calculating the highest, lowest and standard deviation.

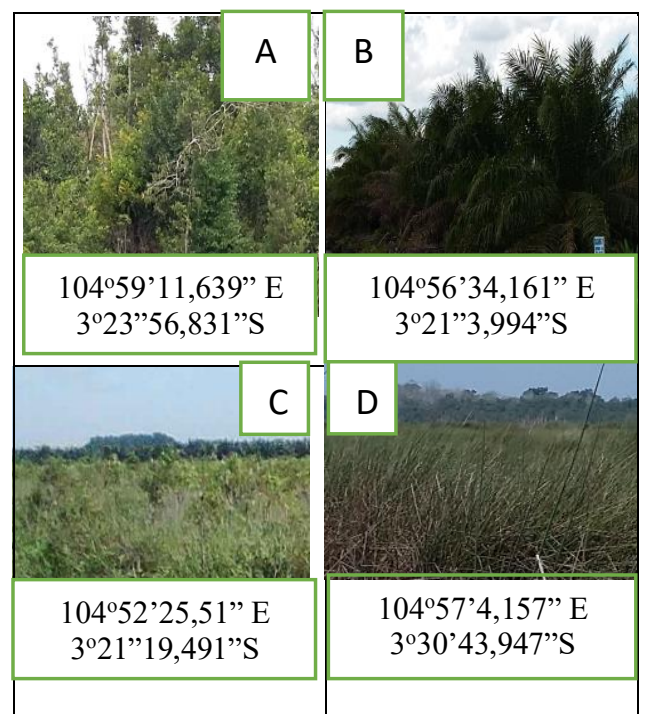

Fig. 1. Location Point of each land use sample A. (secondary forest), B.(Oil palm), C. (Bush), D (grass) 


\section{Results and Discussions}

\subsection{Climate Condition}

Peat is an area that is often flooding, especially in the rainy season. The main Factor affect the condition of peat soil is rainfall. Monthly rainfall exceeds $200 \mathrm{~mm}$ categorized as wet months, $100-200 \mathrm{~mm}$ categorized as intermediate months and less than $100 \mathrm{~mm}$ dry months. The average monthly rainfall from January to December for the past ten years was presented on Fig 2. Rainfall on June, July and August 2018 was 178 mm, 43 mm and 90 $\mathrm{mm}$ respectively. June was categorized as intermediate months, July and August categorized as dry months. This condition resulted on the July and August water levels being drastically reduced. The water level on each land used was presented on Fig 3.

The capillary water of peat soil reached a maximum height $50 \mathrm{~cm}$ [11] so if water table more than $50 \mathrm{~cm}$ under surface, the soil moisture will be drop drastically. On June water table on the site between from $25 \mathrm{~cm}$ to 42 and this level caused the high soil moisture. On July and August water level were $45-60 \mathrm{~cm}$ and $75-80 \mathrm{~cm}$ representatives. The more water level of peat, the dryer of peat soil surface.

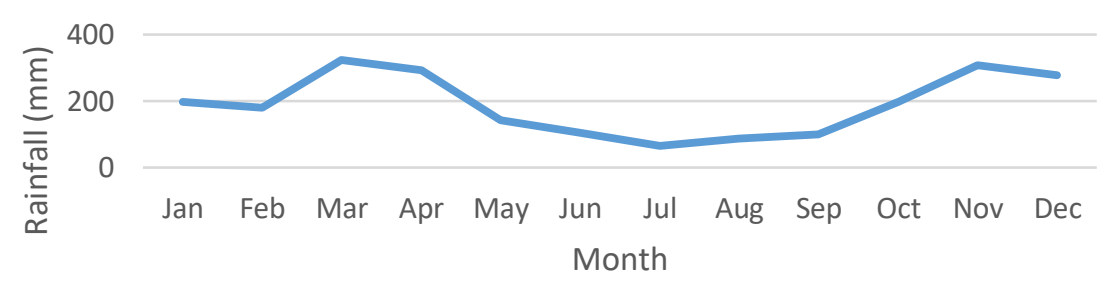

Fig. 2. Average monthly rainfall for the past ten years

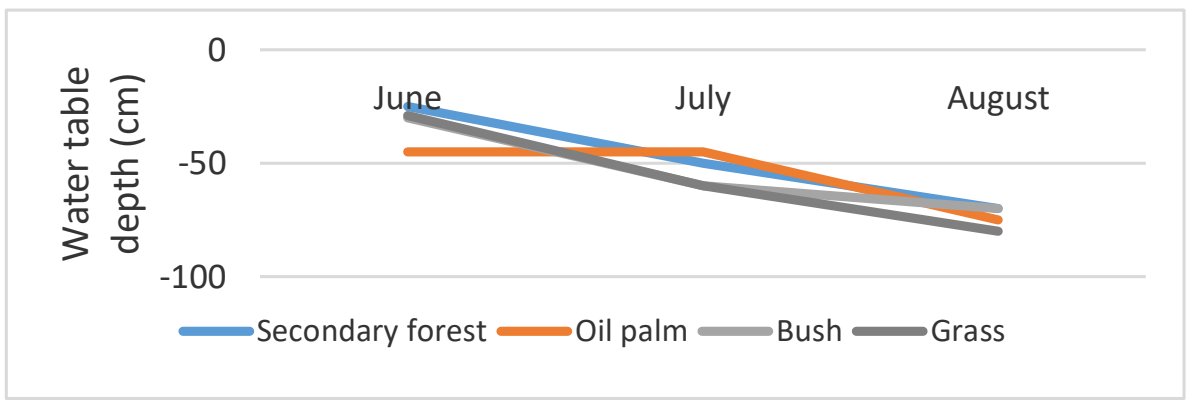

Fig. 3. Monthly water table depth of each land use

\subsection{Characteristics of Each Land Use.}

There are four land uses in the site, on the secondary forest grew some trees as top layer that reach $8 \mathrm{~m}$ height followed by bush and grass as under layer. On the bush grew dominated seduduk (Melastoma sp.) and on the grass grew dominated by purun (Eleocharis dulcis) and oil palm age 4 years with $5 \mathrm{~m}$ height. Soil under secondary forest, oil palm, bush and grass has each BD $0.15 \mathrm{~g} / \mathrm{cm}^{3}, 0.23 \mathrm{~g} / \mathrm{cm}^{3}, 0.20 \mathrm{~g} / \mathrm{cm}^{3}$ and $0.25 \mathrm{~g} / \mathrm{cm}^{3}$ 
representatives. It showed that conversion from forest to non forest has increased the BD of peat because it has decomposed.

Drainage of peat land has decreased the quality of peat properties namely porosity, hydraulic conductivity and organic matter [12,13]. Conversion from forest to non forest has declined the quality of peat physical properties [14]. Secondary forest has high vegetation and no tillage so that the peat decomposed slowly.

The forest ecosystem has good ability to absorb rainwater and to hold high water compared to shrubs and grasses because it has long root[8]. Soil on the under secondary forest has lower bulk density because decomposition in this site still low. High density in the forest so the soil evaporation is lower than other land use.

Table 1. Characteristics of peat soil and vegetation of each land use

\begin{tabular}{|c|c|c|c|c|}
\hline Desciption & $\begin{array}{c}\text { Secondary } \\
\text { forest }\end{array}$ & Oil palm & Bush & Grass \\
\hline $\mathrm{pH}$ & 3.5 & 4.2 & 4.1 & 4.4 \\
\hline Bulk density $\left(\mathrm{g} / \mathrm{cm}^{3}\right)$ & 0.15 & 0.23 & 0.20 & 0.25 \\
\hline C-organic(\%) & 48 & 38 & 37 & 34 \\
\hline Height vegetation $(\mathrm{m})$ & 7 & 4 & 3 & 2 \\
\hline
\end{tabular}

\subsection{Peat Soil Moisture and Fire Risk}

Peat Soil moisture has been determined as the main factor affecting ignition and propagation the smouldering. It is important to control the soil moisture because it is effective way to prevent the fire. Characteristics of vegetation that grow on peat land will influenced the soil moisture.

Monthly peat soil moisture during the research was presented on Figure 4. On June 2018 the peat soil water content in various land uses was still high, ranging from 481 to 518 percent. This is because the rainfall this time is still high at $178 \mathrm{~mm}$ and the water level is 25 to $42 \mathrm{~cm}$. In this month peat on a variety of safe uses from fires.On July 2018, it had a low rainfall of $43 \mathrm{~mm}$ causing the groundwater to drop in the range between $45 \mathrm{~cm}$ to 60 $\mathrm{cm}$ but the water content of peat soil in that month was still high, ranging from 335 to 472 percent. In general, peat soils this month are safe. On August, which is the second month of the dry month which has a low rainfall of $98 \mathrm{~mm}$ so that it affects the water level and causes ground water to begin to drop drastically. Groundwater content began to be categorized as moderate fires in the use of oil palm, bush and grass land.

Soil moisture on August at $0-10 \mathrm{~cm}$ peat depth at grass, oil palm and bush was classified moderate fire risk but on secondary forest was low. This is because forest has vegetation with high stand and long root and high stand coverage. This condition caused hydrology cycle move well. On the other hand grass, oil palm and bush has low coverage so that evaporation this area from peat soil was high. 


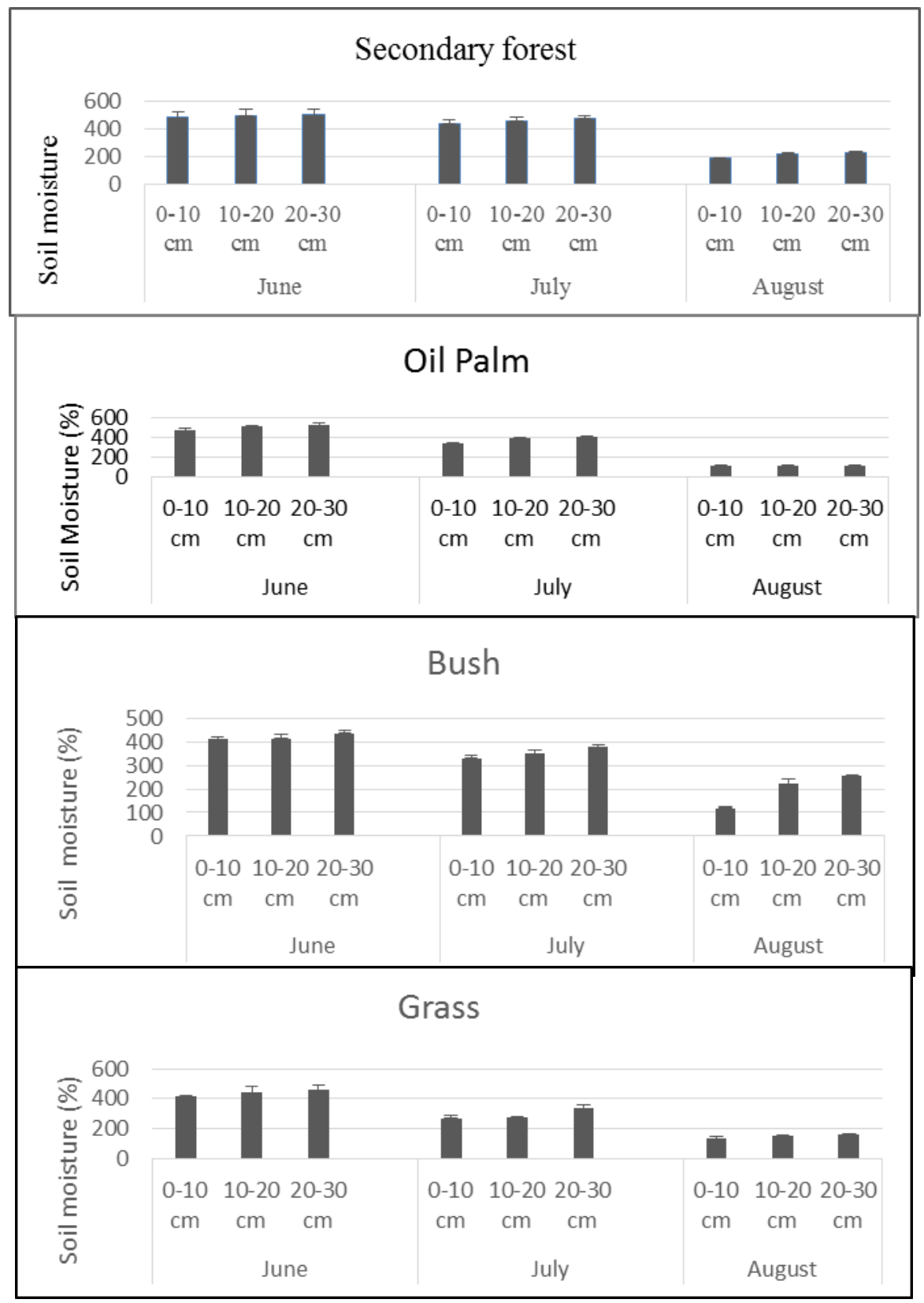

Fig. 4. Monthly soil moisture variability of each land used

\section{Conclusion}


Conversion peat land from forest to other land use would increase the bulk density and it would influence the soil moisture. On the second month of the dry season all peat soil to $30 \mathrm{~cm}$ depth have soil moisture category moderate risk fire except on secondary forest category low risk fire. Monitoring the peat soil moisture would be useful to control and prevent the fire.

\section{Acknowledgments}

We sincerely acknowledge The Ministry of Technology, Research and Higher Education (RISTEKDIKTI) of Republik of Indonesia for the financial support.

\section{References}

1. S. Wahyunto, S. Ritung, and H. Subagjo, Sebaran gambut dan kandungan karbon di Sumatera dan Kalimantan. Proyek Climate Change, Forests and Peatlands in Indonesia (Wetlands International-Indonesia Programme and Wildlife Habitat Canada, Bogor, 2005)

2. A. Hooijer et al. J. Biogeosciences 7, 5 (2010)

3. J. Miettinen and S. C. Liew. J. Ambio 39, 6 (2010)

4. K. H. Lim, S. . Lim, P. F., and R. Suharto, RSPO Manual on best management practices (BMPS) forexisting oil palm cultivation on peat (RSPO, 2012)

5. Holidi, Hermanto and D. Irawanto, "Pertumbuhan Bibit Kelapa Sawit ( Elaeis guineensis Jacq .) dI Media Gambut Pada Berbagai Tinggi Muka Air The Growth of Palm Oil ( Elaeis guineensis Jacq .) Seedlings on Peat Soil Media in Various of Water Table," no. September, Prosiding Seminar Nasional Lahan Suboptimal (2014)

6. Holidi, E. Safriyani, and Sutejo. J. Ilmu Pertanian 18, 3 (2015)

7. R. E. Keane, Wildland Fuel Fundamental and Application (Springer, 2015)

8. C C Park, Tropical Rain Forest (United Kingdom: Taylo \& Francis E-Library, 2003)

9. S. Najiyati, L. Muslihat, and I. N. N. Suryadiputra, Panduan pengelolaan lahan gambut untuk pertanian berkelanjutan (Wetland Indonesia-Indonesia Programme, Bogor, 2006)

10. G. Rein, N. Cleaver, C. Ashton, P. Pironi, and J. L. Torero. J. Catena 74, 3 (2008)

11. N. Imam Muhammad, W. Annisa, L. Syaufina, and S. Anwar. J. Indonesian Journal of Agriculture science 17, 2 (2016)

12. M. E. Armanto, E. Wildayana, M. S. Imanudin, H. Junedi, and M. Zuhdi, Journal of wetlands Environmrntal Management 5, 2 (2017)

13. M. E. Armanto and E. Wildayana. Journal of wetlands Environmrntal Management (2016)

14. H. Junedi, M. E. Armanto, S. Bernas, and M. Imanudin, Sriwijaya Journal of Environment (2017) 